\title{
CARBOHYDRATE METABOLISM OF MYOMETRIUM FROM THE PREGNANT RHESUS MONKEY*
}

\author{
CLARISSA H. BEATTY, GLAYDIS M. BASINGER AND \\ ROSE MARY BOCEK
}

\begin{abstract}
Biochemistry Departments, Oregon Regional Primate Research Center, Beaverton, Oregon 97005, and University of Oregon Medical School, Portland, Oregon
\end{abstract}

(Received 4th Fuly 1968; revised 27th September 1968)

\begin{abstract}
Summary. Slices of uterine muscle from pregnant rhesus monkeys, Macaca mulatta, were incubated in medium containing $\left[1-{ }^{4} \mathrm{C}\right]$ glucose and $\left[6-{ }^{14} \mathrm{C}\right]$ glucose. The $\mathrm{Qo}_{2}$, glucose uptake, and lactate and $\mathrm{CO}_{2}$ production were similar at 92 days $(55 \%$ of gestation) and 155 days ( $93 \%$ of gestation). The data suggest that glycolysis is a more important pathway in pregnant rhesus myometrium than in skeletal muscle. However, only about $0.2 \%$ of the glucose uptake could be accounted for by oxidation via the pentose cycle. Glycogen appeared to be important as an energy reserve during myometrial growth. There was an increase in glycogen levels from the 54th to the 92 nd day of gestation but no evidence that the glycogen level or turnover rate increased near term. The low respiratory quotient $(0 \cdot 7)$ and the small amount of $\left[{ }^{14} \mathrm{C}\right]$ glucose oxidized to $\mathrm{CO}_{2}$ by way of the citric acid cycle (less than $2 \%$ of the glucose uptake), plus the fact that only $5 \%$ of the respired $\mathrm{CO}_{2}$ was produced from $\left[{ }^{14} \mathrm{C}\right]$ glucose suggest that the major energy-source for resting myometrium is lipid rather than carbohydrate.
\end{abstract}

\section{INTRODUCTION}

In spite of considerable current interest in functional disorders of the human uterus, very few observations have been made on the intermediary metabolism of myometrial tissue, especially from pregnant animals, and even fewer on primate myometrium. Brody (1958) found that the glycogen content $(\mu \mathrm{g} / \mathrm{mg}$ dry wt) of the myometrium of seven pregnant women did not change from the 13th to the 40th week of pregnancy, although the concentration was higher throughout pregnancy than in non-pregnant uterine muscle. Lanza (1967) has reported higher values for glycogen synthetase and phosphorylase in human myometrium at term than in non-gravid myometrium, and histochemical evidence has indicated that in pregnant rat myometrium, synthetase and phosphorylase activities and polysaccharide content increased late in pregnancy (Bo \& Smith, 1966). The presence of the glycolytic pathway and pentose and citric acid cycles in uterine tissues has also been established (Needham \& Shoenberg, 1967). However, to our knowledge, no study has been published

* Publication No. 337 of the Oregon Regional Primate Research Center. 
on the relative importance of the pentose cycle (PC) in relation to overall glucose metabolism or of carbohydrate as compared to lipid as an energy source for uterine smooth muscle. Since the levels of creatine phosphate and adenosine triphosphate are 3- to 5-fold lower in the myometrium (Needham \& Shoenberg, 1967) than in skeletal muscle, the myometrium appears to be quite dependent on concurrent metabolism for readily available energy.

In the experiments reported here, myometrial slices from rhesus monkeys (Macaca mulatta) at varying stages of gestation were incubated in media containing $\left[1-{ }^{14} \mathrm{C}\right]$ glucose and $\left[6-{ }^{14} \mathrm{C}\right]$ glucose, and the glucose uptake and conversion of ${ }^{14} \mathrm{C}$ into glycogen, lactate, pyruvate and $\mathrm{CO}_{2}$ were measured. From these data, the relative importance of glycolysis, the PG and the citric acid cycle in the utilization of glucose was estimated. The total $\mathrm{CO}_{2}$ production was also determined so that the percentage of total $\mathrm{CO}_{2}$ derived from the labelled substrate could be measured.

\section{MATERIALS AND METHODS}

\section{Tissues and incubation}

Uterine tissue was obtained at the beginning of Caesarean section from pregnant rhesus monkeys at 50 to 60 (55) days, 85 to 100 (92) days and 150 to 160 (155) days. Since the average gestational period for rhesus monkeys in our colony is about 166 days, the 55-day series represents about $35 \%$, the 92 -day series $55 \%$ and the 155 -day series $93 \%$ of term. In view of the variable length of gestation in different species, it is often more informative to consider specific gestational stages as percentages of the total period. The females were placed with the males for 3 days and the length of gestation was calculated from the 2nd day. Before the Caesarean section, the mother was anaesthetized with 0.5 $\mathrm{mg} / \mathrm{kg}$ phencyclidine or with halothane ( $1 \%$ or less) in a mixture of $75 \%$ oxygen and $25 \%$ nitrogen. No differences were observed between the effects on myometrial motabolism of the two methods of anaesthesia. Biopsies of the same area of the fundus were obtained at Gaesarean section within $5 \mathrm{~min}$ after the peritoneal cavity was opened. Aliquots of myometrium and endometrium (decidua vera) were immediately frozen for glycogen determinations (in situ values). The necessity of avoiding the site of placental attachment occasionally caused a slight variation in the biopsy site. A strip of uterine tissue, about $5 \mathrm{~cm}$ long $\times 1 \mathrm{~cm}$ wide, from which the endometrial tissue had been carefully removed, was cut freehand into slices not more than $1 \mathrm{~mm}$ thick. Histological sections of the stripped myometrium confirmed that the samples were free of endometrial tissue. In a few experiments, the thin endometrial layer ( $1 \mathrm{~mm}$ or less) was cut into pieces about $1 \mathrm{~cm} \times 0.5 \mathrm{~cm}$ for incubation. Preparation of the tissues usually took less than $5 \mathrm{~min}$, during which time the slices were soaked at room temperature in oxygenated Krebs' glycylglycine $(24 \mathrm{~mm}$ ) or phosphate (Umbreit, Burris \& Stauffer, 1957) buffered media, $\mathrm{pH} 7 \cdot 4$, containing $100 \mathrm{mg}$ glucose/100 $\mathrm{ml}\left(\mathrm{NaCl} 123 \mathrm{~mm}, \mathrm{KCl} 1.8 \mathrm{~mm}, \mathrm{CaCl}_{2} 1.7 \mathrm{~mm}, \mathrm{MgSO}_{4} 0.6 \mathrm{~mm}\right.$ and $\mathrm{KH}_{2} \mathrm{PO}_{4}$ $0.6 \mathrm{~mm}$ ). Glycylglycine was usually preferred to phosphate buffered medium because of the pronounced effect of inorganic phosphate on carbohydrate metabolism. Aliquots of muscle, about 200 to $250 \mathrm{mg}$ each, were drained on 
filter paper and placed in weighed Warburg flasks containing $3 \mathrm{ml}$ of medium, $\mathrm{pH} 7.4$ at $37^{\circ} \mathrm{C}$, plus $100 \mathrm{mg}$ of glucose $/ 100 \mathrm{ml}$ in the main chamber and 0.4 $\mathrm{ml}$ of $9.5 \mathrm{~N}-\mathrm{NaOH}$ in one sidearm. The flasks were reweighed, flushed for 5 min with $100 \% \mathrm{O}_{2}$ and incubated for $135 \mathrm{~min}$ at $37^{\circ} \mathrm{C}$. At the end of a 15min equilibration about $1 \cdot 25 \mu \mathrm{Ci}$ of $\left[1-{ }^{14} \mathrm{C}\right]$ glucose or $\left[6-{ }^{14} \mathrm{C}\right]$ glucose were added to each flask $/ \mathrm{ml}$ of medium from a second sidearm. The specific activity of both $\left[1-{ }^{14} \mathrm{C}\right]$ glucose and $\left[6-{ }^{14} \mathrm{C}\right]$ glucose was $2.98 \mathrm{mCi} / \mathrm{m}$-mole.

\section{Analytical methods}

Glucose, lactate, pyruvate and glycogen were determined as previously described (Beatty, Peterson, Basinger \& Bocek, 1966c). It was assumed that the lactate level in the tissues was reflected by that in the medium since after 15-min equilibration, the ratio of the concentration of lactate in the tissue water to the concentration of lactate in the medium was not significantly different from unity. At the end of $15 \mathrm{~min}$ equilibration and $2 \mathrm{hr}$ incubation, $0.1 \mathrm{ml}$ of $18 \mathrm{~N}-\mathrm{H}_{2} \mathrm{SO}_{4}$ was added to the main chamber through a vial closure on a sidearm with a syringe and needle and the flask was shaken for $40 \mathrm{~min}$ to absorb the $\mathrm{CO}_{2}$. The $\mathrm{NaOH}$ was removed from the sidearm under nitrogen and the $\mathrm{CO}_{2}$ values were determined by a modification of the Technicon AutoAnalyzer (N-methodology) micromethod for $\mathrm{CO}_{2}$. Carbon dioxide production was calculated from the value after $135 \mathrm{~min}$ incubation minus the value after $15 \mathrm{~min}$ incubation. The radio-activity of lactate, pyruvate, $\mathrm{CO}_{2}$ and glycogen was measured with a Tracerlab low background counter (20\% efficiency) as previously described (Beatty, Peterson, Basinger \& Bocek, 1966c). Succinic dehydrogenase was estimated both histochemically and quantitatively as previously described (Beatty, Basinger, Dully \& Bocek, 1966b).

Hydroxyproline was estimated according to the method of Woessner (1961) except that the $\mathrm{HCl}$ digest of the muscle was passed through a Dowex-50 column (Moore \& Stein, 1951) to separate hydroxyproline from the rest of the amino acids before colorimetric analysis. The presence in plasma of a non-hydroxyproline chromophore, which interferes with the existing assays for hydroxyproline, has been reported (LeRoy, Kaplan, Udenfriend \& Sjoerdsma, 1964). However, after passage through the Dowex-50 column, no interfering chromophore was present in the hydroxyproline fraction. The amount of collagen, the principal protein of white connective tissue, was calculated from the hydroxyproline values on the assumption that hydroxyproline represents $13.4 \%$ of collagenous protein (Newman \& Logan, 1950; Harding \& Wesley, 1968). In addition, non-collagenous proteins were separated from their supporting tissues by extraction of the non-collagenous protein into $0.05 \mathrm{~N}-\mathrm{NaOH}$ (Lilienthal, Zierler, Folk, Buka \& Riley, 1950) and nitrogen determinations done on the supernatant (non-collagen) and residual (collagen and elastin) fractions. The elastin fraction was also separated (Lowry, Gilligan \& Katersky, 1941) and nitrogen determinations were performed. From these data, the percentage of total nitrogen in the collagen and elastin was calculated. The data in this paper are reported in terms of non-collagenous protein nitrogen (NCN) to correct for the large amount of the metabolically inactive protein, collagen, present in uterine tissues. Nitrogen was determined with the Technicon Auto- 
Analyzer, after Kjeldahl digestion. Representative samples of muscle were dried to constant weight at $97^{\circ} \mathrm{C}$ and the percentage dry weight determined. Differences in data were not considered significant if the $P$ value was $>0.05$.

\section{Hydroxyproline and nitrogen}

\section{RESULTS}

There were small but statistically significant decreases in percentage dry weight, total nitrogen, and collagen content of myometrium from 55 days $(35 \%$ of gestation) to term (Table 1 ). If one calculates the percentage total nitrogen in collagen, assuming that hydroxyproline represents $13.4 \%$ of the collagenous protein and that collagen is $18 \%$ nitrogen, the values obtained, $38 \%$ at 55 days and $32 \%$ at 155 days, agree with the values obtained by extraction of the tissue with $0.05 \mathrm{~N}$-sodium hydroxide (39 and $27 \%$, respectively).

TABLE 1

DRY WEIGHT, NITROGEN, HYDROXYPROLINE AND GOLLAGEN CONTENT OF MYOMETRIUM FROM PREGNANT RHESUS MONKEYS

\begin{tabular}{|c|c|c|c|}
\hline & \multicolumn{3}{|c|}{ Period of gestation (days) } \\
\hline & 55 & 92 & 155 \\
\hline $\begin{array}{l}\% \text { Dry weight } \\
\text { Nitrogen }(\mathrm{g} / 100 \mathrm{~g} \text { wet wt }) \\
\text { OH proline }(\mathrm{mg} / 100 \mathrm{~g} \text { wet } \mathrm{wt}) \\
\% \text { Collagen } \ddagger\end{array}$ & $\begin{array}{cc}17 \cdot 8 \pm 0 \cdot 2^{*} & (5) \\
2 \cdot 52 \pm 0 \cdot 05^{*} & (7) \\
659 \pm 13^{*} & (5) \\
4.9 & \end{array}$ & $\begin{array}{rr}17 \cdot 5 \pm 0 \cdot 4 & (6) \\
2 \cdot 35 \pm 0 \cdot 08 & (8) \\
610 \pm 24 \% & (10) \\
4 \cdot 6 & \end{array}$ & $\begin{array}{cc}16 \cdot 8 \pm 0 \cdot 3 & (10) \\
2 \cdot 28 \pm 0 \cdot 05 & (8) \\
543 \pm 17 & (12) \\
4 \cdot 1\end{array}$ \\
\hline
\end{tabular}

Values are means \pm S.E.; numbers of animals in parentheses.

* $P$ value 55 day versus 155 day series $<0.01$.

$+P$ value 92 day versus 155 day series $<0.05$.

$\ddagger$ OH proline $\times 7.5$.

The values for the percentage total nitrogen in elastin, $0.8,0.9$ and 1.0 at 55 days and $0.7 \pm 0.09(\mathrm{n}=7)$ at 155 days, are probably somewhat larger than the actual values due to the relatively crude method of analysis. However, since the elastin content of pregnant rhesus uteri was minimal, no further determinations were done.

\section{Oxygen uptake and $\mathrm{CO}_{2}$ production}

The oxygen uptake and $\mathrm{CO}_{2}$ production (Table 2) for myometrium were similar for the 92 -day (55\% of gestation) and 155-day $(93 \%$ of gestation) series. There was no change in the $\mathrm{Qo}_{2}$ in the 1st as compared to the 2nd hr and there was only a $10 \%$ drop in oxygen consumption in the $3 \mathrm{rd} \mathrm{hr}$. Although glucose was the only exogenous substrate, the respiratory quotient (RQ) was not significantly different from 0.70 , the theoretical value for the oxidation of tripalmitin.

The $\mathrm{QO}_{2}$ of endometrium at 155 days' gestation (1.29 $\pm 0 \cdot 05$ S.E. m-mole/g NCN hr, $\mathrm{n}=6$ ) was 1.8 times higher than that of the myometrium and the $\mathrm{CO}_{2}$ production $(1 \cdot 12 \pm 0.15 \mathrm{~m}$-mole $/ \mathrm{g}$ NCN $3 \mathrm{hr}, \mathrm{n}=6)$ was more than double that of the myometrium (Table 2). The endometrial $\mathrm{Qo}_{2}$ was similar in the 
1st and 2nd hr of incubation. The RQ of the endometrium was therefore $0 \cdot 86 \pm 0 \cdot 07$, a typical value for utilization of a mixture of substrates.

\section{Glycolysis and glycogenolysis}

The in situ glycogen values of the myometrium almost doubled during the first half of gestation from an average of $120 \pm 8.5$ S.E. $\mathrm{mg} / \mathrm{g}$ NCN (n = 5) at 54 days to $209 \pm 27 \mathrm{mg} / \mathrm{g}$ NCN $(\mathrm{n}=6)$ at 92 days' gestation. At 155 days, the glycogen content was $204 \pm 24(\mathbf{n}=9)$. Apparently there was no further change in the glycogen concentration during the latter half of gestation. There

TABLE 2

METABOLISM OF UTERINE MUSCLE SLICES INCUBATED IN KREBS' GLYCYLGLYGINE BUFFERED MEDIUM PLUS $\left[6-{ }^{14} \mathrm{G}\right]$ GLUGOSE

\begin{tabular}{|c|c|c|c|}
\hline & \multicolumn{3}{|c|}{ Period of gestation (days) } \\
\hline & 92 & & 155 \\
\hline $\mathrm{O}_{2}(\mathrm{~m}-\mathrm{mole} / \mathrm{g} \mathrm{NCN})^{*}{ }_{2}^{1} \mathrm{hr}$ & $\begin{array}{l}0.69 \pm 0.05 \\
0.69 \pm 0.05\end{array}$ & $\begin{array}{l}(9) \\
(9)\end{array}$ & $\begin{array}{l}0 \cdot 73 \pm 0 \cdot 05 \quad(11) \\
0 \cdot 69 \pm 0 \cdot 07 \quad(11)\end{array}$ \\
\hline $\mathrm{CO}_{2} \underset{\left(\text { counts } / \mathrm{min} / \mathrm{g} \text { NCN } \mathrm{hr} \times 10^{3}\right)}{(\mathrm{m}) \mathrm{g} \text { ) }}$ & $390 \pm \overline{28}$ & (7) & $\begin{array}{cc}0.49 \pm 0.05 \\
320 \pm 32\end{array}$ \\
\hline $\mathrm{RQ}(2 \mathrm{hr})$ & - & & $0.69 \pm 0.03$ \\
\hline $\begin{array}{r}\text { Glycogen (mg/g NCN) equil. } \\
2 \mathrm{hr}\end{array}$ & $\begin{array}{c}135 \pm 13 \\
84 \pm 5\end{array}$ & $\begin{array}{l}(7) \\
(7)\end{array}$ & $\begin{array}{c}155 \pm 20 \\
98 \pm 7\end{array}$ \\
\hline (counts/min/g NCN $2 \mathrm{hr} \times 10^{6}$ ) & $1 \cdot 4 \pm 0 \cdot 1$ & (5) & $1 \cdot 1 \pm 0 \cdot 1$ \\
\hline Glucose uptake (mg/g NCN hr) & $67 \cdot 7 \pm 5 \cdot 4$ & (7) & $66 \cdot 2 \pm 5 \cdot 9$ \\
\hline $\begin{aligned} \text { Lactate prod. } \neq & (\mathrm{mg} / \mathrm{g} \mathrm{NCN} \mathrm{hr}) \\
& \left(\text { counts/min/g NCN hr } \times 10^{6}\right)\end{aligned}$ & $\begin{array}{l}39 \cdot 7 \pm 1 \cdot 8 \\
16 \cdot 8 \pm 0 \cdot 6\end{array}$ & $\begin{array}{l}(7) \\
(6)\end{array}$ & $\begin{array}{l}36 \cdot 0 \pm 1 \cdot 6 \\
15 \cdot 4 \pm 0 \cdot 6\end{array}$ \\
\hline $\begin{aligned} & \text { Pyruvate prod. } ¥(\mathrm{mg} / \mathrm{g} \mathrm{NCN} \mathrm{hr}) \\
&\left(\text { counts } / \mathrm{min} / \mathrm{g} \mathrm{NCN} \mathrm{hr} \times 10^{6}\right)\end{aligned}$ & $\begin{array}{l}3.51 \pm 0.14 \\
1.46 \pm 0.09\end{array}$ & $\begin{array}{l}(7) \\
(6)\end{array}$ & $\begin{array}{l}2.40 \pm 0.21 \dagger(5) \\
0.97 \pm 0.05 \dagger(5)\end{array}$ \\
\hline
\end{tabular}

Muscle slices incubated for $135 \mathrm{~min}$ in $3 \mathrm{ml}$ of Krebs' glycylglycine buffered medium, $\mathrm{pH} 7 \cdot 4$ at $37^{\circ} \mathrm{C}$ plus $1 \mathrm{mg}$ glucose $/ \mathrm{ml}$ medium; gas phase $100 \% \mathrm{O}_{2} \cdot\left[6-{ }^{14} \mathrm{C}\right] \mathrm{Glucose}$ added at end of 15 -min equilibration period. Specific activity of medium glucose $740 \times 10^{3}$ counts/ $\mathrm{min} / \mathrm{mg}$ glucose. Values are means $\pm \mathrm{S}$.E. Numbers of animals in parentheses (duplicate flasks for each animal).

* Non-collagenous protein nitrogen.

$+P$ for difference between the two series $<0.01$.

$\$$ Lactate and pyruvate production calculated from concentration in the medium after 135-min incubation minus concentration in the medium after 15-min incubation (equilibration period).

was no difference in the glycogen levels of the inner circular and outer longitudinal muscle layers. The in situ glycogen level of the endometrium close to term, $471 \pm 70 \mathrm{mg} / \mathrm{g} \mathrm{NCN}$, was more than twice that of the myometrium. Comparison of the glycogen concentrations at the end of equilibrium (Table 2) with the in situ value of $204 \pm 24 \mathrm{mg} / \mathrm{g} \mathrm{NCN}$ (155 days) demonstrated that depletion of glycogen occurred during the preparative procedure and the first $15 \mathrm{~min}$ of incubation (equilibration period). There was a further decrease in glycogen levels during the 2-hr incubation period for both myometrial series (Table 2), although a significant percentage of the ${ }^{14} \mathrm{C}$ from the glucose uptake was found in the glycogen fraction at the end of incubation (Table 3 ). Glucose uptake and 
lactate production by the myometrium were similar at 92 and 155 days' gestation whereas pyruvate production was lower just before term. The glucose uptake of the endometrium, $138 \pm 14 \mathrm{mg} / \mathrm{g} \mathrm{NCN} \mathrm{hr}(\mathrm{n}=6)$, was twice that of the myometrium.

\section{Pentose cycle}

The specific yields of lactate, pyruvate, $\mathrm{CO}_{2}$ and glycogen (percentage of ${ }^{14} \mathrm{C}$ from the $\left[{ }^{14} \mathrm{C}\right]$ glucose uptake $\times 10^{-2}$ appearing in the various fractions) are reported in Table 3 which also includes results from a biopsy on Day 54 of pregnancy. Since these values are similar to those obtained later in pregnancy, no further experiments were carried out at 54 days. There was no significant difference between the two substrates, $\left[1-{ }^{14} \mathrm{C}\right]$ glucose and $\left[6-{ }^{14} \mathrm{C}\right]-$ glucose, for the specific yields of the various products with the exception of

\section{TABLE 3}

SPECIFIG YIELDS* OF UTERINE MUSCLE SLIGES INGUBATED IN KREBS' GLYGYLGLYGINE BUfFered MEDIUM PLUS $\left[1-{ }^{14} \mathrm{C}\right]$ GLUCOSE AND $\left[6-{ }^{14} \mathrm{C}\right]$ GLUCOSE

\begin{tabular}{|c|c|c|c|c|}
\hline & Lactate & Pyruvate & Glycogen & $\mathrm{CO}_{2}$ \\
\hline preg. & {$\left[1-{ }^{14} C\right] G \quad\left[6-{ }^{14} C\right] G$} & {$\left[1-{ }^{14} C\right] G \quad\left[6-{ }^{14} C\right] G$} & {$\left[1-{ }^{14} C\right] G \quad\left[6-{ }^{14} C\right] G$} & {$\left[1-^{14} C\right] G \quad\left[6-{ }^{14} C\right] G$} \\
\hline $54 \uparrow$ & 35,34 & $2 \cdot 4,2 \cdot 4$ & $2 \cdot 4,2 \cdot 5$ & $0 \cdot 9,1 \cdot 1$ \\
\hline $\begin{array}{l}92 \ddagger \\
P S\end{array}$ & ${ }_{\mathrm{NS}}^{36 \cdot 8 \pm 3 \cdot 2}{ }^{37 \cdot 1 \pm 3 \cdot 3}$ & $3 \cdot 0 \pm 0 \cdot 4 \mathrm{NS}^{3 \cdot 0 \pm 0 \cdot 4}$ & $1 \cdot 6 \pm 0 \cdot 2 \mathrm{NS}^{1 \cdot 4} \pm 0 \cdot 2$ & $\underset{<0.005}{1 \cdot 6 \pm 0.1} \quad 0.9 \pm 0.1$ \\
\hline $\begin{array}{c}155 \| \\
P \varsigma\end{array}$ & ${ }_{\mathrm{NS}}^{37 \cdot 0 \pm 3 \cdot 0} \underset{32 \cdot 1}{3} \pm 3 \cdot 0$ & $2 \cdot 1 \pm 0.2 \mathrm{NS}^{1 \cdot 8 \pm 0 \cdot 2}$ & $1 \cdot 3 \pm 0 \cdot 1 \mathrm{NS}^{1 \cdot 1 \pm 0 \cdot 1}$ & $\underset{<0.005}{1.4 \pm 0.1} \quad 0.7 \pm 0.1$ \\
\hline
\end{tabular}

Experimental procedures as in Table 2. Values are means \pm S.E. NS, non-significant.

* \% of label from the glucose uptake times $10^{-2}$ appearing in the various metabolic fractions.

$\dagger$ One monkey, duplicate flasks.

$\ddagger$ Seven monkeys, duplicate flasks.

$\$\left[1-{ }^{14} \mathrm{C}\right] \mathrm{G}$ versus $\left[6-{ }^{14} \mathrm{C}\right] \mathrm{G}$.

\|I Five monkeys, duplicate flasks.

$\mathrm{CO}_{2}$. In the latter case, the $P$ value for the difference was $<0.005$ at both 92 and 155 days' gestation and the ratios for ${ }^{14} \mathrm{CO}_{2}$ production from $\left[1-{ }^{14} \mathrm{C}\right]$ glucose/[6- $\left.{ }^{14} \mathrm{C}\right]$ glucose were 1.8 and $2 \cdot 0$, respectively, an indication of the presence of an active PG. However, since the total amount of $\mathrm{CO}_{2}$ produced averaged less than $2 \%$ of the glucose taken up, the pentose cycle did not appear to be an important pathway in terms of glucose molecules oxidized. When PG activity was calculated by using equation 3 or equation 4 of Katz \& Wood (1963), it was estimated that only about $0.2 \%$ of the glucose uptake was metabolized by the PG in either the 92- or 155-day myometrium.

Equation 3

$$
\frac{\mathrm{G}-\mathrm{1}_{\mathrm{CO}_{2}}-\mathrm{G}-6_{\mathrm{CO}_{2}}}{1-\mathrm{G}-6_{\mathrm{CO}_{2}}}=\frac{3 \mathrm{PC}}{1+2 \mathrm{PC}}
$$

Equation 4

$$
\frac{\mathrm{G}-1_{\mathrm{CO}_{2}}-3 \mathrm{PC} \times \mathrm{Q}}{\left(\mathrm{G}-6_{\mathrm{Co}_{2}}\right) \mathrm{Q}}=\frac{\mathrm{EM}}{\mathrm{EM}+\mathrm{PC}}
$$

G- $1_{\mathrm{CO}_{2}}$ and $\mathrm{G}-6_{\mathrm{CO}_{2}}$ represent the specific yields of $\mathrm{CO}_{2}$ from $\left[1-{ }^{14} \mathrm{C}\right]$ glucose 
and $\left[6-{ }^{14} \mathrm{C}\right]$ glucose, respectively, $\mathrm{PC}$ represents the pentose cycle, and $\mathrm{Q}$ the dilution of the specific activity of the hexose-6-P derived from ${ }^{14} \mathrm{C}$-glucose relative to substrate glucose $[Q=1 /(1+2 \mathrm{PG})$. $\mathrm{EM}$ represents the EmbdenMeyerhof pathway or EM $=1-\mathrm{PC}-\mathrm{NTP}$ and NTP the non-triose phosphate pathway.

Therefore, in spite of the high ratios of specific yields for ${ }^{14} \mathrm{CO}_{2}$ from $\left[1-{ }^{14} \mathrm{C}\right]$ glucose to those from $\left[6-{ }^{14} \mathrm{C}\right]$ glucose, the amount of glucose oxidized by the PC is insignificant. The ratio of specific yields for ${ }^{14} \mathrm{CO}_{2}$ provides a more sensitive criterion for estimating $\mathrm{PC}$ activity than are the ratios for the other products because less than $2 \%$ of the glucose uptake was oxidized to $\mathrm{CO}_{2}$ and therefore a small contribution from the PC makes a large change in this ratio.

\section{Glycylglycine and phosphate buffered media}

There was no difference in glucose uptake, lactate and $\left[{ }^{14} \mathrm{C}\right]$ lactate production, oxygen uptake, and $\mathrm{CO}_{2}$ and ${ }^{14} \mathrm{CO}_{2}$ production in glycylglycine and phosphate buffered media (Table 4). However, the glycogen values for myometrium incubated either for 15 or for $135 \mathrm{~min}$ were lower in phosphate

\section{TABLE 4}

COMPARISON OF METABOLISM BY UTERINE MUSCLE SLICES INCUBATED IN KREBS' GLYCYLGLYGINE AND PHOSPHATE BUFFERED MEDIUM

\begin{tabular}{|c|c|c|}
\hline & Glycylglycine & Phosphate \\
\hline $\mathrm{O}_{2}$ (m-mole/g NCN) $1 \mathrm{hr}$ & $\begin{array}{l}0.70 \pm 0.06 \\
0.68 \pm 0.07\end{array}$ & $\begin{array}{l}0.65 \pm 0.07 \\
0.68 \pm 0.07\end{array}$ \\
\hline $\mathrm{CO}_{2} \underset{\left(\text { counts } / \mathrm{min} / \mathrm{g} \mathrm{NCN} 10^{3} \mathrm{hr}\right)}{ }$ & $\begin{array}{c}0 \cdot 47 \pm 0 \cdot 06 \\
320 \pm 41\end{array}$ & $\begin{array}{l}0.43 \pm 0.05 \\
334 \pm 35\end{array}$ \\
\hline $\mathrm{RQ}(2 \mathrm{hr})$ & $0.67 \pm 0.07$ & $0.64 \pm 0.07$ \\
\hline $\begin{array}{l}\text { Glycogen (mg/g NCN) equil. } \\
\qquad \begin{array}{l}2 \mathrm{hr} \dagger \\
\text { (counts } / \mathrm{min} / \mathrm{g} \mathrm{NCN} 10^{6}, 2 \mathrm{hr} \text { ) }\end{array}\end{array}$ & $\begin{array}{c}140 \pm 12^{*} \\
102 \pm 5^{* *} \\
1 \cdot 2 \pm 0 \cdot 1^{*}\end{array}$ & $\begin{array}{l}120 \pm 6 \\
69 \pm 3 \\
0 \cdot 6 \pm 0 \cdot 1\end{array}$ \\
\hline $\begin{array}{l}\text { Glucose uptake (mg/g NCN hr) } \\
\text { Lactate prod. (mg/g NCN hr) } \\
\quad \text { (counts } / \mathrm{min} / \mathrm{g} \mathrm{NCN} 10^{3} \mathrm{hr} \text { ) }\end{array}$ & $\begin{array}{l}72 \pm 11 \\
42 \pm 7 \\
17 \pm 2\end{array}$ & $\begin{array}{l}68 \pm 7 \\
47 \pm 7 \\
15 \pm 2\end{array}$ \\
\hline
\end{tabular}

Muscle slices incubated in Krebs glycylglycine or phosphate buffered media; gas phase $100 \% \mathrm{O}_{2}$. Other experimental procedures as in Table 2. Values are means $\pm S . E$., duplicate flasks on myometrium of three rhesus monkeys at 140 days' gestation. Statistical analysis based on paired observations.

$* P$ for two series $<0.025$.

** $P$ for two series $<0 \cdot 005$.

$\dagger P$ for equilibrium versus $2 \mathrm{hr}<0.005$.

buffered media, as was the amount of ${ }^{14} \mathrm{C}$ (counts/min/g NCN) incorporated into glycogen. These facts are in agreement with the known effects of inorganic phosphate on glycogen metabolism. However, in view of the effect of inorganic phosphate on a variety of reactions in glycolysis, it is surprising that the phosphate medium had no effect on the other parameters investigated. 


\section{Succinic dehydrogenase}

Histochemically, the pregnant endometrium and myometrium showed similar amounts of succinic dehydrogenase activity. Quantitative analyses, however, demonstrated that the succinic dehydrogenase activity of the endometrium was much higher than that of the myometrium (Table 5). There was no difference in the succinic dehydrogenase activity of the myometrium from 50 to 155 days' gestation whereas the activity of the endometrium was lower close to term.

Table 5

COMPARISON OF SUCGINIC DEHYDROGENASE ACTIVITY IN MYOMETRIUM AND ENDOMETRIUM OF THE PREGNANT RHESUS MONKEY

\begin{tabular}{l|c|c|c}
\hline \multirow{2}{*}{ Days pregnant } & \multicolumn{3}{|c}{ Units* $/ g \mathcal{N C N}$} \\
\cline { 2 - 4 } & Myometrium & Endometrium & $\begin{array}{c}\text { P† myo. versus } \\
\text { endo. }\end{array}$ \\
\hline 50 to 100 days & $39 \pm 3$ & $129 \pm 6$ & $<0 \cdot 005$ \\
150 to 160 days & $44 \pm 3$ & $87 \pm 10$ & $<0.05$ \\
$P 50$ to 100 versus 150 to 160 day series & NS & $<0 \cdot 01$ & \\
\hline
\end{tabular}

Values are means \pm S.E. Six samples (duplicate) in each series.

* Units of succinic dehydrogenase or mg of formazan produced/g NCN.

† Paired observations.

\section{DISCUSSION}

It has been clearly demonstrated histologically (Rosa \& Verlardo, 1959) and biochemically (Telefer \& Hisaw, 1957; Scott \& Lisa, 1960) that endometrium and myometrium have quite distinct properties. For this reason, the data reported in this paper were obtained for the tissues after they had been separated. There are also species differences as regards the two tissues. For instance, the glycogen content of the rat and mouse myometrium is higher than that of the endometrium (Leathem, 1959), but there is twice as much glycogen in the endometrium of the non-pregnant rhesus monkey as in the myometrium (Van Dyke \& Ch'en, 1936). The data reported in this paper demonstrate over twice as much glycogen present in the endometrium of the pregnant rhesus monkey as in the myometrium. In man also, there is more glycogen in the endometrium.

\section{Hydroxyproline and nitrogen}

The values for percentage collagen in the myometrial tissue of pregnant rhesus monkeys (Table 1) are similar to the four values, 3.4 to $4 \cdot 7$, reported by Morrione \& Seifter (1962) for collagen in the pregnant human myometrium (126 to 170 days' gestation) and slightly higher than the value of $3 \cdot 1$ found by Cretius, Hannig \& Beier (1966).

Oxygen uptake and $\mathrm{CO}_{2}$ production

It has been generally accepted that the respiration of smooth muscle is lower than that of striated muscle. However, the values for oxygen consumption and $\mathrm{CO}_{2}$ production reported in Table 2 indicate that when these values are 
calculated in terms of non-stromal or non-collagenous protein, they are similar to those previously reported for voluntary skeletal muscle of the adult rhesus monkey, i.e. $0.70 \mathrm{~m}$-mole/g NCN hr $\mathrm{O}_{2}$ and $0.54 \mathrm{~m}$-mole/g NCN hr $\mathrm{CO}_{2}$ respectively (Beatty, Basinger \& Bocek, 1968). This, however, is a rough comparison since both types of muscle are at rest and in an unphysiological situation. In addition, the experiments reported in this paper were done with rapidly growing tissue and the $\mathrm{QO}_{2}$ may be elevated above the values of uteri from nonpregnant rhesus monkeys. The low $\mathrm{RQ}$ of the myometrium and the small amount of $\left[{ }^{14} \mathrm{C}\right]$ glucose oxidized to ${ }^{14} \mathrm{CO}_{2}$, about $2 \%$, together with the fact that only $5 \%$ of the total $\mathrm{CO}_{2}$ was produced from $\left[{ }^{14} \mathrm{C}\right]$ glucose suggests that the major source of energy for resting myometrium is lipid rather than carbohydrate.

\section{Succinic dehydrogenase}

Succinic dehydrogenase activity is generally accepted as an index of the potential for oxidative metabolism (Telefer \& Hisaw, 1957). These workers have demonstrated that in atrophic or oestrogen-stimulated rat uteri, succinic dehydrogenase activity is similar in the endometrium and myometrium whereas in progestational uteri (treated with oestrogen and then progesterone), the activity in the endometrium is always higher. The fact that the succinic dehydrogenase was also higher in the endometrium of the pregnant rhesus monkey suggests that progesterone may cause an increase in the activity of this enzyme in the endometrium. The higher values reported in this paper for oxygen consumption of the endometrium as compared to that of the myometrium are in agreement with the higher succinic dehydrogenase activities of the endometrium.

\section{Glucose uptake and glycogen levels}

Glycolysis, or the conversion of glucose to lactate, appears to be a more important pathway in pregnant rhesus myometrium than in voluntary skeletal muscle under the conditions of these experiments. Glucose uptake and lactate production (Table 2) of myometrium were almost twice as high as the average glucose uptake, $36 \mathrm{mg} / \mathrm{g} \mathrm{NGN} \mathrm{hr}$, and lactate production, $20 \mathrm{mg} / \mathrm{g} \mathrm{NCN} \mathrm{hr}$, for muscle fibre groups from adult rhesus sartorius (Beatty et al., 1968), although the $\mathrm{QO}_{2}$ for uterine and skeletal muscle was similar.

Glycogen levels in situ almost doubled from 55 days (35\% gestation) to 92 days $(55 \%$ gestation) with no further change by 155 days (near term). This glycogen value ( $204 \mathrm{mg} / \mathrm{g} \mathrm{NCN}$ or $19 \mu \mathrm{g} / \mathrm{mg}$ dry wt) is similar to that for human myometrium ( $23 \mu \mathrm{g} / \mathrm{mg}$ dry wt) near term ( 36 to 40 weeks) reported by Brody (1958) and somewhat lower than the value of $3.8 \mathrm{mg} / \mathrm{g}$ fresh tissue found by Lanza (1967) at term. The increase in glycogen during pregnancy in the rhesus myometrium suggests that this polysaccharide is important as an energy reserve during growth. Our experiments do not indicate that the glycogen level or turnover rate increased close to term.

When the magnitude of glycogenolysis was calculated by comparing the specific activity of the $\left[{ }^{14} \mathrm{C}\right]$ lactate with that of the substrate $\left[{ }^{14} \mathrm{C}\right]$ glucose, it appeared that about $40 \%$ of the lactate must have originated from an un- 
labelled source. The amount of lactate produced from cold glycogen, about $35 \mathrm{mg} / \mathrm{g}$ NCN $2 \mathrm{hr}$, was somewhat less than that expected from the measured decrease in glycogen. However, the calculation based on relative specific activities provides only a minimum estimate of glycogenolysis because some of the $\left[{ }^{14} \mathrm{C}\right]$ glucose undoubtedly forms labelled glycogen which then forms labelled lactate. The major part of the cold lactate was probably formed from glycogen though a minimal amount of unlabelled lactate may have originated from malate or oxaloacetate or from deamination of amino acids. The percentage of label from the glucose uptake appearing in the glycogen fraction of pregnant myometrium (Table 3) was only one-tenth of that appearing in the glycogen fraction of skeletal muscle, although the in situ glycogen levels for myometrium from 92 to 155 days' gestation, calculated on the basis of non-collagenous protein nitrogen (204 to $209 \mathrm{mg} / \mathrm{g} \mathrm{NCN}$ ), were similar to that of predominantly red skeletal muscle of the rhesus monkey, $228 \pm 17 \mathrm{mg} / \mathrm{g}$ NCN (Bocek \& Beatty, 1967).

\section{Pentose cycle}

A number of workers have demonstrated the presence of the PC in rat myometrium (Scott \& Lisa, 1960) and in whole uteri (Warren, Cheatum, Greenwald \& Barker, 1967; Eckstein \& Villee, 1966). In rapidly growing tissues like the pregnant myometrium with a high rate of protein synthesis, one expects an increased need for ribose associated with the increased RNA and DNA content. Therefore, the pathway for ribose synthesis, the PC, might be quantitatively important in this tissue.

The experiments reported in this paper should have spanned the rapid growth phase for the uterus in the rhesus monkey, since Behrman, Seeds, Battaglia, Hellegers \& Bruns (1964) have demonstrated that in this species there is an 8- to 9-fold increase in uterine weight from 58 to 156 days' gestation. However, in the pregnant myometrium, PC activity accounted for only about $0.2 \%$ of the glucose oxidized in the myometrium. These data agree with previous results in rapidly growing foetal muscle where less than $0.5 \%$ of the glucose uptake was metabolized by the PC (Beatty, Basinger \& Bocek, 1966a).

The estimates for $\mathrm{PC}$ activity in vitro are probably close to the in vivo values. Hostetler \& Landau (1967) estimated the PC contribution to glucose metabolism in vivo for several tissues including skeletal muscle and found good agreement with in vitro values. According to Katz \& Rognstad (1967), the contribution of the non-oxidative portion of the $\mathrm{PC}$ is negligible in relation to pentose synthesis. In all cases, including muscle, the net flow of carbon in the nonoxidative branch is from pentose to hexose and in the oxidative branch from hexose to pentose. Thus, the net synthesis of pentose from hexose is caused entirely by the oxidative branch of the PG.

\section{ACKNOWLEDGMENTS}

This investigation was supported in part by Grant FR-00163 of the National Institutes of Health, Public Health Service Research Grants HD-02837 and HD-02836 from the National Institute of Child Health and Human Develop- 
ment and by the Muscular Dystrophy Associations of America. We are indebted to G. W. de Lannoy for obtaining the biopsies.

\section{REFERENCES}

Beatty, C. H., Basinger, G. M. \& Bocek, R. M. (1966a) Pentose cycle activity in muscle from fetal, neonatal, and infant rhesus monkeys. Archs Biochem. Biophys. 117, 275.

Beatty, C. H., Basinger, G. M. \& Bocek, R. M. (1968) Oxygen consumption and glycolysis in fetal, neonatal, and infant muscle of the rhesus monkey. Pediatrics, Springfield, 42, 5.

Beatty, C. H., Basinger, G. M., Dully, C. C. \& Bocek, R. M. (1966b) Comparison of red and white voluntary skeletal muscles of several species of primates. F. Histochem. Cytochem. 14, 590.

Beatty, C. H., Peterson, R. D., Basinger, G. M. \& Bocek, R. M. (1966c) Major metabolic pathways for carbohydrate metabolism of voluntary skeletal muscle. Am. F. Physiol. 210, 404.

Behrman, R. E., Seeds, A. E., Battaglia, F. G., Hellegers, A. E. \& Bruns, P. D. (1964) The normal changes in mass and water content in fetal rhesus monkey and placenta throughout gestation. 7. Pediat. 65, 38.

Bo, W. J. \& Sмітн, M. S. (1966) A histochemical study on the glycogen synthesizing enzyme in the myometrium of the pregnant and pseudopregnant rat. F. Reprod. Fert. 12, 237.

BoceK, R. M. \& BEATTY, C. H. (1967) Glycogen metabolism in fetal, neonatal, and infant muscle of the rhesus monkey. Pediatrics, Spring field, 40,412.

BRODY, S. (1958) Hormonal influences on the glycogen content of the human myometrium. Acta endocr., Copenh. 27, 377.

Cretius, K., Hannig, K. \& Beier, G. (1966) Solubility and behavior of collagen in nonpregnant and pregnant human uteri. Arch. Gynaek. 203, 329.

Eckstein, B. \& Villee, C. A. (1966) Effect of estradiol on enzymes of carbohydrate metabolism in rat uterus. Endocrinology, 78, 409.

Harding, J. J. \& Westey, J. M. (1968) The purification and amino acid composition of human uterus collagens, rheumatoid-arthritis-nodule collagen, and ox tendon collagen. Biochem. F. 106, 749.

Hostetler, K. Y. \& Landay, B. R. (1967) Estimation of the pentose cycle contribution to glucose metabolism in tissue in vivo. Biochemistry, N.Y. 6, 2961.

KaTz, J. \& Rognstad, R. (1967) The labeling of pentose phosphate from glucose- ${ }^{14} \mathrm{C}$ and estimation of the rates of transaldolase, transketolase, and the contribution of the pentose cycle and ribose phosphate synthesis. Biochemistry, N.Y. 6, 2227.

KATz, J. \& Wood, H. G. (1963) Use of $\mathrm{C}^{14} \mathrm{O}_{2}$ yields from glucose-1- and -6- $\mathrm{C}^{14}$ for the evaluation of the pathways of glucose metabolism. 7. biol. Chem. 238, 517.

LANZA, A. (1967) Uridine diphosphoglucose:glycogen $\alpha$-4-glucosyl transferase of human myometrium. Experientia, 23, 287.

Leathem, J. H. (1959) Some biochemical aspects of the uterus. Ann. N.Y. Acad. Sci. 75, 463.

LeRoy, E. C., Kaplan, A., Udenfriend, S. \& Sjoerdsma, A. (1964) A hydroxyproline containing collagen like protein in plasma and a procedure for its assay. F. biol. Chem. 239, 3350.

Lilienthal, J. L., Jr, Zierler, K. L., Folk, B. P., Buka, R. \& Riley, M. J. (1950) A reference base and system for analysis of muscle constituents. F. biol. Chem. 182, 501 .

Lowry, O. H., Gilligan, D. R. \& Katersky, E. M. (1941) Determination of collagen and elastin in tissues, with results obtained in various normal tissues from different species. F. biol. Chem. 139, 795.

Moore, S. \& STEIN, W. H. (1951) Chromatography of amino acids on sulfonated polystyrene resins. J. biol. Chem. 192, 663 .

Morrione, T. G. \& Seifter, S. (1962) Alterations in the collagen content of the human uterus during pregnancy and post partum involution. 7. exp. Med. 115, 357.

NeEdham, D. M. \& Shoenberg, G. F. (1967) Biochemistry of the myometrium. In: Cellular Biology of the Uterus, chap. 9, p. 291. Ed. R. M. Wynn. Appleton-Century-Crofts, New York.

Newman, R. E. \& Logan, M. A. (1950) The determination of collagen and elastin in tissue. 7. biol. Chem. 186, 549.

Rosa, G. G. \& Velardo, J. T. (1959) Histochemical observations of oxidative enzyme systems in the uterus and vagina of the rat. Ann. N.Y. Acad. Sci. 75, 491.

Scotr, D. B. M. \& LISA, A. G. (1960) Changes in enzymes of the uterus of the ovariectomized rat after treatment with oestradiol. Biochem. 7. 77, 52 .

Telefer, M. A. \& Hisaw, F. L., JR (1957) Biochemical responses of the rabbit endometrium and myometrium to oestradiol and progesterone. Acta endocr., Copenh. 25, 390.

Umbreit, W. W., Burris, R. H. \& Stauffer, J. F. (1957) Manometric techniques, p. 149. Burgess, Minneapolis, Minnesota. 
VAN DYKe, H. B. \& CH'EN, G. (1936) Observations on the biochemistry of the genital tract of the female macaque particularly during the menstrual cycle. Am. F. Anat. 58, 473 .

Warren, J. G., Cheatum, S. G., Greenwald, G. S. \& Barker, K. L. (1967) Cyclic variations of uterine metabolic activity in the golden hamster. Endocrinology, 80, 714.

WoEssNer, J. F., JR (1961) The determination of hydroxyproline in tissue and protein samples containing small proportions of this imino acid. Archs Biochem. Biophys. 93, 440. 